\title{
CEREBELLAR DEGENERATION AND IMMUNE THROMBOCYTOPENIC PURPURA ASSOCIATED WITH HUMAN IMMUNODEFICIENCY VIRUS INFECTION (HIV)
}

\author{
Clécio de Oliveira Godeiro-Júnior, André Carvalho Felício, \\ Orlando Graziani Povoas Barsottini, Alberto Alain Gabbai
}

\begin{abstract}
Cerebellar disorders associated with HIV infection are usually caused by opportunistic infections, central nervous system lymphoma, and toxic effects of medicines, nutritional and metabolic disorders, and cerebrovascular disease. We present an unusual association of cerebellar degeneration and immune thrombocytopenic purpura in a 28 -years-old woman HIV infected. An autoimmune aetiology is likely.
\end{abstract}

KEY WORDS: HIV, autoimmunity, cerebelar degeneration, immune thrombocytopenic purpura.

\begin{abstract}
Degeneração cerebelar e púrpura trombocitopênica imunológica associados à infecção pelo vírus HIV
RESUMO - Transtornos cerebelares associados a infecção pelo HIV são comumente causados por infecções oportunistas, linfoma do sistema nervoso central, efeitos tóxicos de medicamentos anti-retrovirais, alterações metabólicas e nutricionais, e doença cerebrovascular. Apresentamos um caso incomum de associação de degeneração cerebelar e púrpura trombocitopênica imunológica em um mulher de 28 anos infectada pelo HIV. Discutimos uma possível etiologia autoimune para justificar o quadro.
\end{abstract}

PALAVRAS-CHAVE: autoimunidade, degeneração cerebelar, púrpura trombocitopênica imunológica.

The spectrum of cerebellar disorders occurring in association with human immunodeficiency virus (HIV) is large due to opportunist infections, primary central nervous system (CNS) lymphoma, toxic effects of medicines, nutritional and metabolic disorders, cerebrovascular disease and direct action of HIV ${ }^{1,2}$. Although immune thrombocytopenic purpura (ITP) has been related to HIV infection ${ }^{3.4}$, its association with cerebellar degeneration (CDeg) is unusual.

We here report a patient with CDeg and ITP as a prime manifestation of HIV infection. An autoimunne mechanism is considered to explain both clinical manifestations.

\section{CASE}

A 28-year-old white woman was referred to our hospital due to 8-month history of progressive slurred speech, unsteady gait, and limb clumsiness. She had no previous history of alcohol or drug abuse. Family history was negative for neurological diseases and her parents were not consanguineous. Neurological examination disclosed normal cognitive status, bilateral horizontal nystagmus, marked gait ataxia and limb dysmetria and dysdiadochokinesia. On brain magnetic resonance imaging (MRI) prominent cerebellar atrophy was seen, mainly in the vermis (Figure). Cerebrospi- nal fluid analysis was unremarkable. Her first laboratory evaluation was negative for HIV, syphilis, cytomegalovirus, toxoplasmosis and Cryptococcus serology. Antinuclear and anticardiolipin antibodies were negative. Associated with the onset of neurological symptoms she presented menorrhagia and on that time hematological exams disclosed

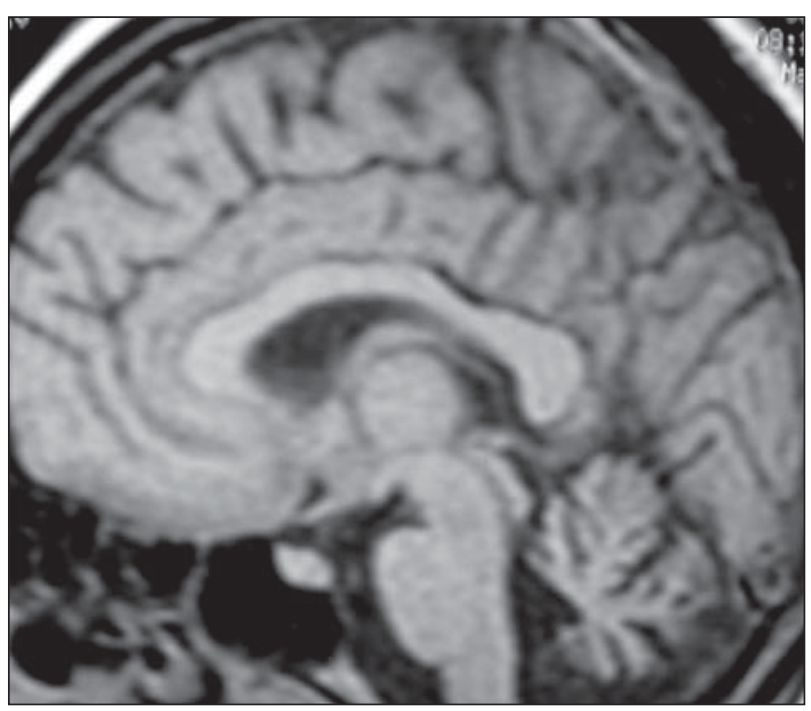

Figure. MRI showing cerebellar atrophy, mainly in the vermis.

Department of Neurology and Neurosurgery, Escola Paulista de Medicina, Universidade Federal de São Paulo, São Paulo SP, Brazil. Received 12 February 2007, received in final form 31 May 2007. Accepted 2 August 2007. 
mild anemia (hemoglobin=10.8 g/dL) and thromobocytopenia (platelets $=21000 / \mathrm{mm}^{3}$ ). Bone marrow biopsy was compatible with ITP. All previous laboratory tests were repeated four months later and once again were negative, except for HIV which was positive with total $\mathrm{CD}_{4}$ count of 34 cells/ $\mathrm{mm}^{3}$. She was treated with immunoglobulin and corticosteroids for IPT, and an antiretroviral regimen with stavudine, lamivudine, lopinavir and ritonavir. After a follow-up of 12 months, her hematological disorder had improved and cerebellar disorder was the same.

We obtained informed consent from the patient for publishing this case report.

\section{DISCUSSION}

HIV-1 is a retrovirus which produces profound CD4 depletion, possibly through an initial massive depletion of gut-associated memory T-cells, and then chronic immune activation, leading to fatigue of homeostatic T-cell responses and progressive immunodeficiency'. Chronic immune activation with HIV infection progression leads to deregulation of macrophages, with the overproduction of various proinflammatory cytokines and chemokines within the CNS 5 .

Cerebellar syndrome has been reported to precede the complex HIV-dementia in the absence of cerebellar lesion ${ }^{6,7}$. CDeg, however, due to direct action of HIV virus is exceptional ${ }^{8,9}$. Pathophysiology seems to be autoimmunne leading to apoptosis of Purkinje and granular cerebellar cells due to the potential toxic effects of cytokins involved in this mechanism ${ }^{8-10}$. Cerebellar granular neurons in culture displayed abnormalities in neurotransmitter-induced calcium transients when exposed to interleukin- $6^{10}$.

Thrombocytopenia in HIV infection is caused by platelet immune-mediated destruction, in addition to inadequate platelet production ${ }^{3}$. Patients with early HIV-1 infection and therefore an intact immune system develop thrombocytopenia as a consequence of antibody attachment direct to platelet immunodominant epitopes ${ }^{11}$.

The association of CDeg and IPT makes this case report unusual. An infectious trigger responsible for immune activation is one of the postulated mechanisms for the development of autoimmunity and derives from molecular mimicry ${ }^{12}$. In HIV infection, autoimmune diseases occur when there is no immunossupression such as during acute infection or following highly active antiretroviral therapy - HAART ${ }^{10}$. Cerebellopontine degeneration has already been described in the setting of immune restoration following HAART therapy in a HIV patient ${ }^{13}$. Progressive cerebellar syndrome as the first manifestation of HIV infection has already been described ${ }^{14}$. In this case, we believe that the HIV infection acted as a trigger for immune activation, leading to production of citokins and antibodies, which caused both CDeg and IPT.

\section{REFERENCES}

1. McArthur JC, Brew BJ, Nath A. Neurological complications of HIV infection. Lancet Neurol 2005;4:543-555.

2. Berger JR. AIDS and the Nervous System. In Aminoff MJ (Ed). Neurology and general medicine. 3.Ed. Philadelphia: Churchill Livingstone, 2001:743-762.

3. Coyle TE. Hematologic complications of human immunodeficiency virus infection and the acquired immunodeficiency syndrome. Med Clin N Am 1997;81:449-470.

4. Louache F, Vainchenker W. Thrombocytopenia in HIV infection. Curr Opin Hematol 1994;1:369-372.

5. Gartner S. HIV infection and dementia. Science 2000;287:602-604.

6. Graus F, Ribalta T, Abos J, et al. Subacute cerebellar syndrome as the first manifestation of AIDS dementia complex. Acta Neurol Scand 1990; 81:118-120.

7. Yebra M, Garcia-Merino A, Albarran F, Varela JM, Echevarria JM. Cerebellar disease without dementia and infection with the human immunodeficiency virus (HIV). Ann Intern Med 1988;108:310- 311.

8. Tagliati M, Simpson D, Morgello S, Clifford D, Scwartz RL, Berger JR Cerebellar degeneration associated to human immunodeficiency virus infection. Neurology 1998;50:244-251.

9. Kwakwa HA, Ghobrial MW. Primary cerebelar degeneration an HIV. Arch Intern Med 2001;161:1555-1556.

10. Holliday J, Parsons K, Curry J, Lee Sy, Grual DL. Cerebellar granule neurons develop elaveted calcium responses when treated with interleukin-6 in culture. Brain Res 1995;673:141-148

11. Li Z, Nardi MA, Karpatkin S. Role of molecular mimicry to HIV-1 peptides in HIV-1-related immunologic thrombocytopenia. Blood 2005;106: 572-576.

12. Shoenfeld Y. Common infections, idiotypic dysregulation, autoantibody spread and induction of autoimmune diseases. J Autoimmun 1996; 9:235-239.

13. Kinzel N, Strike D, Clark HB, Cavert W. Cerebellopontine degeneration as an immune restoration disease in HIV infection. AIDS 2004;18:23482350.

14. Puertas I, Jiménez-Jiménez FX, Gómez-Escalonilla C, et al. Progressive cerebellar syndrome as the first manifestation of HIV infection. Eur Neurol 2003;50:120-121. 